Ks. Bogdan CZYŻEWSKI*

\title{
GRZECH KAINA W OCENIE OJCÓW KOŚCIOŁA
}

Ojcowie Kościoła i pisarze wczesnochrześcijańscy pozostawili komentarze do Księgi Rodzaju, w których wyjaśniali, niekiedy zdanie po zdaniu, biblijne opisy początków świata i człowieka. Wielokrotnie też interpretowali tekst Rdz 4, 1-16, w którym mowa jest o grzechu Kaina ${ }^{1}$.

W niniejszym opracowaniu chcemy przedstawić ocenę grzechu Kaina dokonaną przez Ojców Kościoła ${ }^{2}$. Ukażemy tutaj myśli tylko wybranych autorów, ponieważ trudno jest dokonać prezentacji wszystkich wypowiedzi na ten temat, tym bardziej że pojawiały się one nie tylko w komentarzach do Księgi Rodzaju, ale także w innych dziełach, o czym można się przekonać czytając jakąkolwiek literaturę patrystyczną. Grzech Kaina wzbudzał uzasadnione emocje, ponieważ było to bratobójstwo ${ }^{3}$. Aby dokonać rzetelnej oceny postępowania Kaina, komentowano wszystkie wersety Księgi Rodzaju, które odnosiły się wprost do niego. Czyniono tak zwłaszcza wtedy, gdy interpretowano całą wspomnianą księgę biblijną. W pismach patrystycznych i nieco późniejszych zdarzają się też nader często wypowiedzi oderwane od bezpośredniej egzegezy Księgi Rodzaju, wtrącone natomiast do tekstów, w których podejmuje się inną tematykę, jako przykład niegodnego zachowania człowieka.

* Ks. dr hab. Bogdan Czyżewski, prof. UAM - profesor nadzwyczajny w Zakładzie Teologii Patrystycznej i Historii Kościoła na Wydziale Teologicznym Uniwersytetu im. Adama Mickiewicza w Poznaniu; e-mail: czybo@amu.edu.pl.

${ }^{1} \mathrm{~W}$ niniejszym artykule wykorzystamy przede wszystkim komentarze do Księgi Rodzaju dwóch Ojców Kościoła: Efrema Syryjskiego (Ephraem Syrus, Commentarius in Genesim, ed. R.M. Tonneau, CSCO 152 (Scriptores Syri 71), Louvain 1955) i Jana Chryzostoma (Joannes Chrysostomus, In Genesim hom., PG 53, 21 - 54, 580). Pozostałe teksty pochodzą z wybranych dzieł okresu patrystycznego (oprócz Bedy Czcigodnego i Symeona Nowego Teologa, niezaliczanych do grona Ojców Kościoła, ponieważ żyli po VIII w.), w których poruszony został temat grzechu Kaina.

${ }^{2} \mathrm{Z}$ biblijnego punktu widzenia opowiadanie o Kainie należy do tzw. prehistorii biblijnej. Współczesna zaś egzegeza nie kładzie nacisku na historyczność tej postaci lecz akcentuje naukę moralną o konsekwencjach zazdrości i gniewu, por. R. Rubinkiewicz, Kain, EK VIII 328.

${ }^{3}$ Należy również dodać, że jest to owoc wcześniej popełnionego grzechu przez Adama i Ewę (por. Rdz 3, 1-24). Grzech pierwszych rodziców rozszerza się bowiem wielokierunkowo w postaci osobistych grzechów i dotknął ich potomka - Kaina, por. L. Stachowiak, Grzech pierworodny, EK VI 282. 
1. Grzech gniewu i zazdrości. Zanim przejdziemy do tekstów, w których bezpośrednio jest mowa o zbrodni $\mathrm{Kaina}^{4}$, warto najpierw przyjrzeć się tej tragicznej postaci i grzechom, które doprowadziły do zabójstwa Abla. Okazuje się, że Ojcowie Kościoła analizując teksty biblijne mówiące o Kainie dochodzili do ciekawych wniosków nie tylko natury teologicznej, ale także moralnej z punktu widzenia oceny postępowania tego człowieka.

Św. Jan Chryzostom stwierdza, że Kain został poczęty dopiero po grzechu Adama i Ewy, wcześniej bowiem pierwsi rodzice ,żyli jak aniołowie i nie znali uciech ciała"'. Symeon Nowy Teolog natomiast twierdzi, że Kain został poczęty, ponieważ Adam zwrócił swą miłość w stronę widzialnych rzeczy. Narodziny Kaina były konsekwencją upadku Adama, który doprowadził go do utraty jego duchowej mądrości i do nabycia ziemskiego poznania:

„Zaślepione zaś oczy jego duszy, odsunięty od życia niezniszczalnego, zaczął patrzeć oczami ciała i kierując wzrok swoich oczu z uczuciem żądzy na rzeczy widzialne «rozpoznał swoją żonę Ewę, a ona poczęła i urodziła Kaina» (por. Rdz 4, 1). Taki sposób poznania jest w rzeczywistości nieznajomością tego wszystkiego, co jest dobre, ponieważ jeśliby najpierw nie odsunął poznania i kontemplacji Boga, nie zostałby doprowadzony do tej wiedzy"6.

Św. Augustyn z kolei wyjaśnia znaczenie imienia Kain. Według niego oznacza ono:

„«posiadanie». Stąd owe słowa, wypowiedziane przez ojca czy przez matkę po jego narodzeniu się: «Otrzymałam człowieka przez Boga» $(\operatorname{Rdz} 4,1)$ "”.

Pisarze Kościoła pierwszych wieków zastanawiali się także nad znaczeniem słów opisujących ofiarę, jaką złożył Kain Bogu i wyjaśniali, dlaczego nie została przez Niego przyjęta. Zaznaczają jednocześnie, że Bóg nie potrzebuje ofiar. Fakt przyjmowania ich, zauważania, bądź też odrzucania, o czym jest mowa w Piśmie Świętym, świadczy wyłącznie o trosce Boga o człowieka. Składanie ofiar ${ }^{8}$ pomaga bowiem ludziom czcić Boga, nie pomagają one natomiast w żaden sposób samemu Bogu? .

${ }^{4}$ Więcej informacji na temat etymologii imienia Kain i samego Kaina, por. P.Cz. Bosak, Leksykon wszystkich postaci biblijnych, Kraków 2015, 920.

${ }^{5}$ Joannes Chrysostomus, In Genesim hom. 10, 12, PG 53, 153, thum. własne.

${ }^{6}$ Simeon (Novus Theologus $=$ Simeon Junior), Catecheses 15, 16-24, ed. B. Krivochéine, SCh 104, Paris 1964, 222-224, tłum. własne.

${ }^{7}$ Augustinus, De civitate Dei XV 17, PL 41, 461, tłum. W. Kornatowski: Św. Augustyn, O Państwie Bożym, II, Warszawa 1977, 192.

${ }^{8} \mathrm{Na}$ temat składania ofiar można znaleźć w Piśmie Świętym wiele tekstów. Spotykamy je bowiem na przestrzeni całej historii zbawienia. Więcej o ofiarach opisanych w Biblii por. Słownik Teologii Biblijnej, red. X. Léon-Dufour, tłum. K. Romaniuk, Poznań - Warszawa 1982, 610-615.

${ }^{9}$ Por. Augustinus, Epistula 102, 16, ed. A. Goldbacher, CSEL 34/2, Vindobonae 1898, 558559, tłum. własne: „Napisane jest, iż Kain złożył Bogu w ofierze dar z owoców ziemi, Abel zaś z pierworodnych owiec; dlatego zrozumiałe jest, że lepsza jest stara rzecz, którą składano w ofierze, 
Dla św. Efrema Syryjczyka ważny jest także wybór darów ofiarnych. Abel - jego zdaniem - wybrał je bardzo starannie, Kain natomiast nie dokonał żadnego ich wyboru:

„Abel przyniósł wybrane spośród pierworodnych i tłustych, Kain zaś przyniósł kłosy, a wraz z nimi owoce, które dojrzewały w czasie dojrzewania kłosów. Choć jego ofiara była mniejsza od ofiary jego brata, jeśli nie zostałaby przyniesiona $\mathrm{z}$ niedbalstwem, zostałaby przyjęta tak jak ofiara jego brata Abla, ponieważ podobne składali ofiary: jeden ofiarował jagnięta ze swej trzody, a drugi owoce ziemi. Ale ponieważ Kain na początku ofiary był niedbały [Bóg] nie chciał przyjąć jego [darów], aby pouczyć go, jak należy składać ofiarę"10.

Orygenes uważa, że odrzucenie ofiary Kaina przez Boga spowodowane było obecnością grzechu w sercu Kaina. Aleksandryjczyk określa go grzechem złości. Ujawnił się, co prawda, dopiero w chwili zabicia Abla, lecz o wiele wcześniej opanował serce Kaina ${ }^{11}$. Złość Kaina, według św. Jana Chryzostoma, dostrzegalna była w smutku, jaki pojawił się na jego twarzy, a powód takiego zachowania był podwójny: „Pan odrzucił jego ofiarę i przyjął ofiarę Abla"12. Efrem Syryjczyk jest tego samego zdania, wyjaśnia bowiem, że Kain

„był zły, ponieważ została przyjęta ofiara jego brata. Zezłościł się zatem z powodu ognia, który opadając [ku ziemi] odróżnił ofiary. I posmutniała jego twarz z powodu śmiechu w oczach jego rodziców i sióstr, gdy ofiara jego została odrzucona. Widzieli bowiem, że włożył ofiarę do ognia, ale ogień do niej się nie zbliżał"13.

W wypowiedziach Ojców Kościoła na temat sytuacji, jaka miała miejsce jeszcze przed zabiciem Abla, podkreślona zostaje i doceniona inicjatywa Boga względem Kaina. Chodzi mianowicie o Boże miłosierdzie, które towarzyszy człowiekowi po popełnieniu grzechu. Bóg próbuje pomóc Kainowi, zwłaszcza, że znając jego myśli i serce, wie o zamiarze popełnienia przez niego kolejnego, o wiele gorszego grzechu. Pisze o tym św. Jan Chryzostom:

która, o czym przypominają prawdziwe i święte pisma, nie powinna być ofiarowana jak tylko jedynemu prawdziwemu Bogu, nie dlatego, że Bóg potrzebowałby jej, ale dlatego, że w tych samych pismach wyraźnie zostało napisane: «jesteś moim Bogiem, ponieważ nie potrzebujesz moich darów» (Ps 15, 2), lecz także, kiedy coś z nich przyjmuje, albo odrzuca, albo zauważa, troszczy się tylko o ludzi. Nam bowiem pomaga, że czcimy Boga, nie samemu Bogu".

${ }^{10}$ Ephraem Syrus, Commentarius in Genesim III 2, CSCO 152, 47, tłum. własne wg R.M. Tonneau, CSCO 153, Louvain 1955, 36.

${ }^{11}$ Por. Origenes, De oratione 29, 18, PG 11, 543, thum. W. Kania - H. Pietras, w: H. Pietras, Odpowiedź na Stowo. Najstarsi mistrzowie chrześcijańskiej modlitwy, Kraków 1993, 225-226: „Również złość Kaina powstała nie wtedy dopiero, gdy zabił swego brata, bo już przedtem nie wejrzał Bóg, znawca serc, na niego i na jego ofiarę, ale przy zamordowaniu Abla ujawniła się jego złość”.

${ }^{12}$ Joannes Chrysostomus, In Genesim hom. 18, 21, PG 53, 156, tłum. własne.

${ }^{13}$ Ephraem Syrus, Commentarius in Genesim III 3, CSCO 152, 48, tłum. własne wg Tonneau, CSCO 153, 37. 
„Podziwiajcie więc, z jaką dobrocią Pan szuka sposobu, by złagodzić wściekłość i gniew Kaina, i przez jakie łagodne słowa stara się uciszyć uniesienie jego gniewu. Widzi niepokój i poruszenie jego serca oraz zna jego okrutne i zbrodnicze zamiary. Dlatego próbuje wyjaśnić jego rację i, aby wprowadzić do jego duszy spokój i zadowolenie zapewnia, że jego brat będzie jemu uległy i nie utraci na tym jego autorytet. Lecz tak wiele dobroci i uprzejmości okazały się bezużyteczne. Kain nic nie skorzystał i upierał się w swojej złośliwości i w zawziętości"14.

Ten sam wątek podejmuje św. Efrem Syryjczyk, który wkłada w usta Boga słowa, jakimi wyjaśnia powód nieprzyjęcia ofiary Kaina:

„Powiedział mu Bóg: «Dlaczego jesteś zły i pochmurniało twoje oblicze» (por. Rdz 4, 6). Zamiast gniewu, który cię napełnił, powinien wypełnić cię smutek i zamiast spochmurniałego oblicza, łzy winny popłynąć z twych oczu. Gdybyś bowiem postępował dobrze, wziąłbym ją [tj. ofiarę]. Zauważ zatem, że nie z powodu skromności ofiary, została ona odrzucona. Nie została przyjęta z powodu jego złego życia i braku cnót. «Jeśli bowiem postępowałbyś dobrze, wziąłbym ją, nawet jeśli wcześniej jej nie zabrałem, i wraz z wyborną ofiarą twego brata zostałaby przyjęta, nawet jeśli wcześniej nie została przyjęta. Jeśli zaś nie będziesz postępował dobrze, grzech przyczai się u wejściowych drzwi. Oto Abel zwróci się ku tobie i przez posłuszeństwo, pójdzie $z$ tobą na równinę ${ }^{15}$, a ty jesteś opanowany przez grzech. On bowiem cię wypełnia» (por. Rdz 4, 7). Zatem Kain, zamiast postępować dobrze, aby móc liczyć na przyjęcie ofiary, która została odrzucona, do ofiary, którą złożył w nieprawości, dodał ofiarę zabójstwa"16.

$\mathrm{Z}$ treści przytoczonych tekstów wynika, że Ojcowie Kościoła dokładnie analizowali zachowanie Kaina. Okazuje się, że ważna dla nich była jego postawa przed zabiciem Abla. W komentarzach do Rdz 4, 1-7 pisarze wczesnochrześcijańscy zdecydowanie piętnowali zazdrość, jaką owładnięty został Kain, oraz wszystkie inne grzechy, które ona zrodziła: złe myśli, gniew, brak szczerego serca podczas składania ofiary Bogu. Ojcowie Kościoła, komentując wspomniane fragmenty, podkreślali także gotowość pomocy Kainowi ze strony Boga. Wystarczyło żałować i zwrócić się do Niego, by otrzymać przebaczenie. Postawa Kaina, jeszcze przed popełnieniem zabójstwa Abla, z moralnego punku widzenia została bardzo mocno skrytykowana. Brakuje w niej bowiem jakichkolwiek oznak nawrócenia. Trwanie Kaina w grzechu pociągnęło go do popełnienia kolejnego grzechu. Należy również zaznaczyć, że Bóg ofiarowując Kainowi wsparcie, chciał mu pomóc wyjść z pokusy

${ }^{14}$ Joannes Chrysostomus, In Genesim hom. 18, 24, PG 53, 157-158, thum. własne.

${ }^{15}$ Pole lub równina poza Edenem, gdzie został zabity Abel.

${ }^{16}$ Ephraem Syrus, Commentarius in Genesim III 4, CSCO 152, 48-49, tłum. własne wg Tonneau, CSCO 153, 37-38. 
i odnaleźć wewnętrzny spokój, a zwłaszcza pokazać, że problem tkwi w samym Kainie, nie zaś w Bogu, ani też w Ablu ${ }^{17}$.

2. Grzech zabójstwa Abla. Ojcowie Kościoła kreśląc obraz Kaina, próbowali na różne sposoby dociec, jaka była przyczyna grzechu zabójstwa, którego dopuścił się na swoim bracie Ablu ${ }^{18}$. Symeon Nowy Teolog wprost pyta: „Dlaczego Kain dopuścił się bratobójstwa? Czyż nie było to z powodu jego złej woli?"19 i jednocześnie odpowiada:

„Wolał siebie od swojego Stwórcy i poszedł za złymi myślami, i został w ten sposób opuszczony z powodu zazdrości i popełnionego morderstwa"20.

Ponownie pojawia się grzech zazdrości jako powód zabójstwa Abla. Zazdrość spowodowała tak wielkie spustoszenie w życiu Kaina, że nie był w stanie zapanować nad złem, które nosił w sobie. Można nawet pokusić się o stwierdzenie, że grzech zabójstwa brata nosił długo w sobie, planował go, ponieważ cały czas przesiąknięty był złą wolą złymi myślami i zazdrością.

Ojcowie podejmowali też w swoich wypowiedziach ciekawy wątek możliwości nawrócenia, jakie zaproponował Bóg Kainowi. Okazuje się, że ta inicjatywa ze strony Boga powtórzyła się także po zabójstwie brata. Sw. Efrem Syryjczyk stwierdza, że Bóg objawił się Kainowi

„będąc w życzliwym usposobieniu, aby jeśli się nawróci, poprzez żal jego ust, został zapomniany grzech zabójstwa popełniony jego rękami. Jeśli zaś się nie nawróci, zostanie mu zasądzona surowa kara, odpowiednia do jego złego grzechu"21.

Kain odrzucił jednak żal, o czym św. Efrem Syryjczyk wspomina w dalszej części swojego Komentarza do Księgi Rodzaju. Podkreśla, że

„zamiast żalem napełnił się gniewem i Bogu, który zapytał go o brata, aby go odzyskać, Kain odpowiedział ze złością, mówiąc: «Nie wiem. Czy jestem stróżem mego brata?» (Rdz 4, 9). [...] Cóż Kainie mówisz? Czy Sprawiedliwość wzięła pomstę za krew, która woła głośno do niego, czy też nie? Czy nie zwleka, abyś się nawrócił? Czy nie oddaliła się od swej wiedzy i zapytała cię, jakby nie wiedząc, żeś to wyznał? Stąd, ponieważ nie podobało się tobie to,

${ }^{17}$ Por. B. Costacurta, Obietnica życia w Księdze Rodzaju, thum. D. Piekarz, Kraków 2005, 65.

${ }^{18} \mathrm{~W}$ odróżnieniu od Symeona Nowego Teologa, Biblia nie podaje żadnego powodu tego czynu. Można jedynie powiedzieć, że w judaizmie Abel jest postrzegany jako typ dobra, Kain zaś jako typ zła, por. Praktyczny Stownik Biblijny, red. A. Grabner-Haider, thum. T. Mieszkowski - P. Pachciarek, Warszawa 1994, 3.

${ }^{19}$ Simeon, Catecheses 4, 72-74, ed. B. Krivochéine, SCh 96, Paris 1963, 320, thum. własne.

${ }^{20}$ Tamże, tłum. własne.

${ }^{21}$ Ephraem Syrus, Commentarius in Genesim III 6, CSCO 152, 49, thum. własne wg Tonneau, CSCO 153, 38. 
co ci teraz powiedziała, lecz doszedłeś do grzechu, przed którym cię ostrzegała, abyś do niego nie przystapił?"22

Orygenes określa Kaina jako zbrodniczego i niegodziwego człowieka, natomiast krew Abla, według niego, symbolizuje niesprawiedliwie przelaną krew męczenników ${ }^{23}$.

Św. Jan Chryzostom zwraca uwagę na karę wymierzoną przez Boga Kainowi. Uznaje ją za łagodna a nawet wychowawczą dla niego samego oraz dla potomnych. Biskup Konstantynopola stwierdza, że na pierwszy rzut oka słowa Boga wypowiedziane do Kaina, iż ma być uciekinierem i wędrowcem na ziemi,

„wydawały się surowe i przytłaczające, ale były dowodem wielkiej życzliwości. Ponieważ, pragnąc pouczyć potomków, [Bóg] wybrał taki rodzaj kar, który mógł Kaina oczyścić z grzechu; gdyby natychmiast uśmiercił [Kaina], pogrzebałby razem z nim jego zbrodnię i potomni niczego by się nie dowiedzieli. Natomiast, pozostawiając Kainowi długi żywot w konwulsjach, uczynił z niego nauczyciela wszystkich, którzy się z nim spotkali; swoim wyglądem i drżeniem członków napominał, aby nie ośmielili się popełniać podobnego czynu, aby nie skazali się na podobne męki. Sam [Kain] stał się przez to lepszym, gdyż konwulsje, obawy, niespokojne życie, ułomność fizyczna, trzymały go, jak na łańcuchu i nie pozwalały popełnić nowej zbrodni; zarazem stale przypominały o dawnym grzechu, a duszę jego uczyły rozsądku"24.

O małej karze dla Kaina wspomina także św. Cyryl Jerozolimski, który dostrzega w niej miłość Boga do ludzi. Zwracając się do katechumenów poucza ich:

„Czy chcesz, od niedawna uczęszczając na katechezy, zobaczyć miłość Boga ku ludziom? Czy chcesz zobaczyć miłość Boga ku ludziom i Jego wielką hojność? Posłuchaj historię [Kaina] [...] Kain, dopuścił się bratobójstwa, dał początek złu, był pierwszym zabójcą i zazdrośnikiem. Jaki jednak otrzymał wyrok po zabiciu brata: «Będziesz wzdychał i drżał na ziemi» (por. Rdz 4, 12; LXX). Wielki grzech, a mała kara"25.

${ }^{22}$ Tamże III 6-7, CSCO 152, 49-50, thum. własne wg Tonneau, CSCO 153, 38-39.

${ }^{23}$ Origenes, Exhortatio ad martyrium 50, PG 11, 634-635, tłum. S. Kalinkowski: Orygenes, Zachęta do męczeństwa, PSP 24, Warszawa 1980, 172: „Zdajemy sobie sprawę wreszcie i z tego, co powiedziano o Ablu zabitym przez zbrodniczego i niegodziwego Kaina, odnosi się do tych wszystkich, których krew została niesprawiedliwie przelana. Wiedzmy bowiem, że zdanie: «głos krwi brata twego woła do mnie z ziemi» (Rdz 4, 10), mówi o każdym z męczenników, że jak my zostaliśmy odkupieni przez drogą krew Jezusa".

24 Joannes Chrysostomus, Adversus Judaeos or. 8, 2, PG 48, 930, thum. J. Iluk: Św. Jan Chryzostom, Mowy przeciwko Judaizantom i Żydom, ŹMT 41, Kraków 2007, 211.

${ }^{25}$ Cyrillus Hierosolymitanus, Ad illuminandos catechesis 2, 7, PG 33, 391, thum. W. Kania: Cyryl Jerozolimski, Katechezy przedchrzcielne i mistagogiczne, BOK 14, Kraków 2000, 40. 
Zewnętrznym i widocznym znakiem kary wymierzonej Kainowi przez Boga było znamię, jakie otrzymał. Miało ono uchronić go przed zabiciem przez innych. Ojcowie dostrzegali w tym znamieniu znaczenie teologiczne. Św. Ambroży z Mediolanu uważa, że znak ten był dany Kainowi,

„aby go nikt nie zabił. Przez to zaznaczono, iż zła na ziemi się nie wyniszczy, nie usunie się go z niej. Kain bał się, że go zabija, bo nie umiał uciec. Złość się pomnaża i zwiększa przez wprawianie się do niej; nie ma ona ani miary, ani końca; objawia się podstępem, oszustwem, swymi czynami, krwią tych, których zabija, jak się to okazało w Kainie"26.

Według Ojców Kościoła otrzymane przez Kaina znamię należy interpretować $\mathrm{w}$ tym znaczeniu, że zło pochodzące z ziemi jest niezniszczalne. Podobnie jak Kain, który otrzymał znamię i jest niszczony przez strach, tak też grzesznik staje się niewolnikiem strachu, pożądania, winy i gniewu. Biskup Mediolanu nie ogranicza się jednak wyłącznie do analizowania winy Kaina. Swoją interpretację uaktualnia i odnosi do całej ludzkości. Dostrzega mianowicie w każdym grzeszniku podobieństwo do Kaina:

„Zobacz, do jakiego stopnia Kain jest niewolnikiem, skoro mówi: «Mam się ukrywać przed toba, i być tułaczem i zbiegiem na ziemi, każdy, kto mnie spotka, będzie mógł mnie zabić» (Rdz 4, 14). Tak więc jako niewolnik otrzymał znamię, jednak nawet w ten sposób nie mógł ujść gwałtownej śmierci. Grzesznik jest więc niewolnikiem strachu, jest także niewolnikiem pożądliwości, niewolnikiem chciwości, niewolnikiem pożądania, niewolnikiem złośliwości, niewolnikiem gniewliwości; i taki człowiek wydaje się sam sobie wolny, jednakże jest w niewoli gorszej, niż gdyby był poddany tyranom"27.

Św. Ambroży w zacytowanym powyżej tekście wiele razy powtarza słowo „niewolnik”. Dla niego jakikolwiek grzech nie czyni człowieka wolnym, lecz grzeszący traci prawdziwą wolność, staje się niewolnikiem. Jak Kain, który otrzymał znamię i niszczony był przez strach, tak też grzesznik jest niewolnikiem popełnionego przez siebie grzechu. Na tym nie kończy się psychologiczna i moralna analiza portretu Kaina. Św. Jan Chryzostom cofnął się do wcześniejszej historii, konkretnie zaś do sytuacji, jaka miała miejsce w raju. Biskup Konstantynopola porównał Kaina do węża z ogrodu Eden i stwierdził, że uczynił

„on prawie tak samo, jak wąż, podobnie jak on posłużył jako narzędzie diabła, jak on użył podstępu, by wprowadzić na świat śmierć, ponieważ wprowadził

${ }^{26}$ Ambrosius, De fuga saeculi 7, 39, ed. K. Schenkl, CSEL 32/2, Vienna 1897, 194, thum. W. Szołdrski: Św. Ambroży, O ucieczce od świata, w: Św. Ambroży, Wybór pism, PSP 7, Warszawa $1971,117$.

${ }^{27}$ Tenże, Epistula 7, 31, ed. O. Faller, CSEL 82/1, Vienna 1968, 58, thum. P. Nowak: Św. Ambroży, Listy (1-35), t. 1, BOK 9, Kraków 1997, 78. 
w błąd swego brata, kiedy wyprowadził go na pole a chwytając go za rękę, zabił go. Bóg, który przeklął węża: «Będziesz przeklęty pośród zwierząt na ziemi» (Rdz 3, 14), w taki sam sposób przeklął Kaina, którego czyn podobny był do tego, jakiego dopuścił się wąż"28.

Opisane w Biblii sytuacje są rzeczywiście bardzo podobne i użyte przez św. Jana Chryzostoma porównanie wydaje się całkowicie uzasadnione oraz trafne. W jednym bowiem i drugim przypadku mamy do czynienia z grzechem i karą za niego. Biskup podkreślił też zgubne i podstępne działanie diabła na węża i na Kaina. Owocem uległości wobec szatana stała się śmierć, której poddani zostali mieszkańcy ziemi.

Św. Jan Chryzostom zwraca uwagę na jeszcze jeden ważny element postawy Kaina. Podobnie jak inni komentatorzy fragmentu biblijnego mówiącego o grzechu Kaina, Złotousty zastanawia się nad przyznaniem się przez niego do winy. Chryzostom stwierdza, że - co prawda - Kain w końcu przyznał się do winy, lecz nie odniosło to jednak żadnego skutku w formie przebaczenia. Stało się tak, ponieważ:

„wyznanie przychodzi zbyt późno. Zobaczcie, powinien uczynić to w odpowiednim czasie, kiedy był w stanie znaleźć miłosierdzie u sędziego"29.

Jak rozumieć to stwierdzenie św. Jana Chryzostoma? Z jednej strony Ojcowie Kościoła idąc za licznymi przykładami biblijnymi przypominają o możliwości nawrócenia w każdym czasie i chwili, z drugiej zaś jakby ograniczali je i stawiali mu ramy czasowe. Wydaje się, że Biskup Konstantynopola zdecydowanie staje po stronie człowieka i daje świadectwo o miłosierdziu Bożym. Jest jednak zdania, że grzesznik nie powinien zwlekać z ujawnieniem swojej winy, ale od razu należy przyznać się do popełnionego grzechu i w ten sposób się nawrócić. W przeciwnym razie może zaskoczyć go śmierć i wówczas postawa opieszałości okaże się dla niego zgubna.

Należy jeszcze wspomnieć o ciekawej interpretacji grzechu Kaina dokonanej przez Bedę Czcigodnego. Można dostrzec u niego typologiczne i alegoryczne odczytanie biblijnego tekstu mówiącego o śmierci Abla. Św. Beda stwierdza mianowicie, że zabicie Abla zapowiada mękę Chrystusa:

„Lecz jeśli zrozumieją, że zbrodnia Kaina jest zdradą Żydów, że zabójstwo Abla jest męką Pana, Zbawiciela, że ziemia, która otwarła swoje usta i przyjęła Jego krew z ręki Kaina jest Kościołem, który otrzymał w tajemnicy swojego odnowienia krew Chrystusa rozlaną przez Żydów, bez wątpienia odkryli wodę przemienioną w wino, ponieważ uważają święte słowa za świętsze od prawa"30.

${ }^{28}$ Joannes Chrysostomus, In Genesim hom. 19, 11, PG 53, 162, thum. własne.

${ }^{29}$ Tamże 19, 3, PG 53, 163, tłum. własne.

${ }^{30}$ Beda Venerabilis, Homiliarum ewangelii 1, 14, ed. D. Hurst, CCL 122, Turnhout 1955, 99, tłum. własne. 
$\mathrm{Z}$ całą pewnością mamy tutaj do czynienia z zastosowaniem podwójnej interpretacji tekstu biblijnego. Można nawet powiedzieć, że dwie metody egzegetyczne: typologia i alegoria wzajemnie się przenikają i na siebie nakładają do tego stopnia, że trudno jest jednoznacznie określić ich granice. Postępując tokiem myślenia Bedy Czcigodnego w sensie typologicznym i jednocześnie alegorycznym zbrodnia Kaina zapowiada i jest zdradą Chrystusa dokonaną przez Żydów, śmierć Abla to obraz męki Chrystusa, ziemia przesiąknięta krwią Abla to figura Kościoła, w którym obecna jest Krew Chrystusa dzięki sprawowanej w nim Eucharystii. Ale chodzi tutaj także o Krew Chrystusa przelana na drzewie krzyża, która oczyszcza Kościół, ponieważ sprawiła, że ludzkość dzięki śmierci Zbawiciela na drzewie krzyża została pojednana z Bogiem.

Pośród wyliczanych grzechów w związku ze zbrodnią dokonaną przez Kaina na Ablu, Ojcowie wymieniają także kłamstwo. Chodzi tutaj o chęć zatajenia grzechu przez Kaina. Pytany przez Boga o brata, stwierdził, że nie wie, gdzie on się znajduje (por. Rdz 4, 9). Kainowi wydawało się, że może oszukać Boga. Salwian z Marsylii w dziele O rzqdach Boga potępia tego rodzaju postawę i stwierdza:

,już Kain wyrażał pogląd, który teraz tak wielu ma zwolenników, mianowicie, że Bóg nie zwraca uwagi na to, co dzieje się na ziemi i nie widzi zbrodniczych czynów ludzi. I nie ma co do tego żadnej wątpliwości, że gdy po popełnieniu zbrodni został Bożym wezwaniem upomniany, odpowiedział, że nic nie wie o zabójstwie brata. Do tego stopnia uważał, że Bóg nie jest świadomy jego czynu, iż wierzył, że za pomocą kłamstwa może ukryć akt w najwyższym stopniu zbrodniczego bezprawia. To, co go spotkało, było czymś zupełnie innym, niż myślał: albowiem gdy został skazany, poznał, że Bóg, o którym sądził, iż nie widzi jego zbrodni, jednak ją dostrzega" ${ }^{31}$.

Poczynione powyżej uwagi przez Salwiana z Marsylii miały na celu uświadomienie ludziom, by nie zatajali popełnionych przez siebie grzechów. Każda bowiem ludzka wina znana jest Bogu i niczego nie jesteśmy w stanie przed Nim ukryć.

Maksym z Turynu zwraca uwagę na jeszcze jeden ważny moment w zbrodni Kaina. Odwołując się do słów Boga wypowiedzianych do Kaina: „Głos krwi twojego brata woła do mnie" (Rdz 4, 10) przypomina o sumieniu, które posiada każdy człowiek. Ono jest niezmiernie istotnym głosem, który pozwala dokonać właściwej oceny moralnej każdego czynu. Maksym z Turynu, nawiązując do wspomnianego biblijnego wyrażenia „głos krwi”, stwierdza:

„Krew mianowicie nie ma żadnego głosu, lecz jest powiedziane, że krew, którą niewinny wylał woła, jednak nie słowem lecz z powodu sprawcy, i że

${ }^{31}$ Salvianus Massiliensis, De gubernatione Dei I 6, 29, ed. G. Lagarrigue, SCh 220, Paris 1975, 126, tłum. T. Kołosowski: Salwian z Marsylii, O rzqdach Boga, w: Salwian z Marsylii, Dzieła wszystkie, PSP 66, Warszawa 2010, 108-109. 
Pan sprzeciwia się nie z powodu ochrony sposobu mówienia, ale z oburzenia za popełniony grzech. A ponadto swojego winowajcę nie tyle mowami słów oskarża, co ujarzmia jego sumienie oskarżeniem. Chociaż bowiem zły czyn, jeśli jest popełniony w słowach, prawdopodobnie otrzymuje usprawiedliwienie, jeśli odwołuje się do sumienia, nie może być usprawiedliwiony. Tajemnicze sumienie bowiem bez sprzeciwu zawsze wykazuje winę i sądzi swojego winowajcę"32.

W powyższej wypowiedzi Maksym z Turynu kładzie nacisk na osąd sumienia, który zawsze pozostanie niezmiernie ważnym głosem po popełnieniu grzechu. Niewinna krew przelana przez Kaina krzyczy nie przez słowa, lecz przez to, że Abel prawdziwie był niewinny. Dlatego też sumienie, które wyrzuca ten grzech pozostanie na zawsze dobrze słyszanym przez wszystkich głosem. On upomina się o sprawiedliwość i sąd dla tego, kto dopuścił się takiego rodzaju grzechu.

3. Skutki grzechów Kaina. Dotychczasowa analiza tekstów patrystycznych odnoszących się do $\mathrm{Rdz} 4$, 1-16 daje podstawę do tego, że nie należy mówić o jednym grzechu w przypadku Kaina, ale o licznych winach. Przed zabiciem brata Abla dostrzec można było w zachowaniu Kaina zazdrość, złe myśli, gniew, nieszczerość serca, potem też kłamstwo, czyli próbę ukrycia grzechu. Ojcowie zwracają zatem uwagę na rodzenie przez jeden grzech kolejnych grzechów. One też posiadają konkretne negatywne skutki dla przyszłych pokoleń, co było widoczne w życiu Kaina.

Św. Atanazy Wielki podkreśla, że skutkiem grzechu Kaina było opuszczenie przez niego Boga:

„Poprzez sprawiedliwość dojdziemy przed oblicze Boże, jak uczynił Mojżesz, kiedy wszedł do gęstego obłoku, w którym był Bóg (por. Wj 19, 20). Z drugiej strony, przez praktykowanie zła osoba opuszcza Pana. Na przykład, Kain, kiedy zabił swego brata, opuścił Pana, w znaczeniu tego, co dotyczyło jego nastawienia do ludzi"33.

Nie tylko odejście od Boga było negatywnym skutkiem grzechu Kaina. Opuścił także swoich krewnych, o czym pisze św. Efrem Syryjczyk:

„Po tym jak Kain otrzymał karę, dodano mu znamię - ponieważ o przyczynie tego wystarczająco powiedzieliśmy, więcej nie powiemy, ponieważ nie jest to konieczne - powiedziane zostało: «Kain odszedł sprzed oblicza Pana i osiadł w ziemi Nod, na wschód od Edenu» (Rdz 4, 16 ). Oddzielił się zatem

${ }^{32}$ Maximus Taurinensis, Sermo 88, 1, ed. A. Mutzenbecher, CCL 23, Turnhout 1962, 359, tłum. własne.

33 Athanasius, Epistulae festales (versio syriaca) 10, The Festal Letters of Athanasius in an ancient Syriac Version, ed. W. Cureton, London 1848, 46, thum. własne z angielskiego. 
od swoich rodziców i braci, gdyż widział, że nie będzie się z nimi łączył przez małżeństwo" 34 .

Skutkiem grzechu Kaina było nie tylko jego odejście od rodziny. Św. Efrem Syryjczyk pisze w Hymnie o raju także o podzieleniu się rodziny Kaina i Abla, co niewątpliwie miało również swoje negatywne oddziaływanie na inne rodziny:

„Tam rodziny

dwóch braci zostały rozdzielone:

Kain poszedł sam

i zamieszkał w kraju Nod,

w miejscu jeszcze niższym

niż Set i Enosz;

lecz ci, którzy żyli na wyższym terenie,

którzy zostali nazwani

«dziećmi Bożymi»,

opuścili swoją krainę i zamieszkali na dole,

aby pojąć żony

spośród córek Kaina"35.

Wątek opuszczenia Boga i krewnych przez Kaina po popełnieniu przez niego grzechu Ojcowie Kościoła rozwijają na wszelkie sposoby. Skupiaja swoją uwagę na nazwie kraju Nod. Uważają, że możliwa jest różna jej interpretacja. Klemens Aleksandryjski w Kobiercach używa nazwy Naid i wyjaśnia ją w następujący sposób:

„Słusznie więc napisano: «Odszedł Kain sprzed oblicza Pana i zamieszkał w ziemi Naid, naprzeciw Edenu» (Rdz 4, 16). Naid oznacza zamęt, Eden rozkosz. Wiara, gnoza i pokój są tą rozkoszą, z której nieposłuszny jest wyłączony. A ten, kto siebie samego za mądrego uważa [...] rzuca się dobrowolnie w wir wzburzonych fal, rezygnując z poznania bytu nie mającego początku na korzyść rzeczy ludzkich i stworzonych oraz przeskakując z jednej opinii do drugiej" ${ }^{36}$.

Klemens Aleksandryjski zestawia ze sobą dwie nazwy: Naid i Eden. Są one przeciwieństwem, podobnie jak to ma miejsce w przypadku gnostyka i tego, który nim nie chce być. Jak w Edenie wszystko było rozkoszą, przez co autor

${ }^{34}$ Ephraem Syrus, Commentarius in Genesim III 11, CSCO 152, 52, thum. własne wg Tonneau, CSCO 153, 40-41.

${ }^{35}$ Tenże, Hymni de Paradiso 1, 11, ed. E. Beck, CSCO 174, Louvain 1957, 3, tłum. własne wg E. Beck, CSCO 175, Louvain 1957, 3.

${ }^{36}$ Clemens Alexandrinus, Stromata II 51, 4-5, PG 8, 987, tłum. J. Niemirska-Pliszczyńska: Klemens Aleksandryjski, Kobierce zapisków filozoficznych dotyczacych prawdziwej wiedzy, t. 1, Warszawa 1994, 164. 
rozumie posłuszeństwo Bogu w postaci wiary, poznania i pokoju serca, tak w kraju Naid panował zamęt, czyli świadome wyłączenie się z poznania Boga.

Dla św. Efrema Syryjczyka natomiast nazwa krainy Nod oznacza ,wędrowanie". Prawdopodobnie wyprowadza taką a nie inną terminologię w związku z kara, jaką otrzymał Kain po popełnieniu zbrodni bratobójstwa. Miał stać się tułaczem i zbiegiem (por. Rdz 4, 12). Nawiązując do tego wątku, Efrem wyjaśnia:

„Ziemię zaś nazwano Nod, ponieważ była ziemią drżącego i trzęsącego się Kaina. Niemniej otrzymał on także drugie przekleństwo, kiedy Bóg powiedział: «Gdy będziesz uprawiał tę ziemię, nie dołoży ona swych sił, aby cię obdarować» $(\operatorname{Rdz} 4,12)^{\prime 37}$.

Efrem Syryjczyk zwraca uwagę na ciąły strach i niepokój, jaki odczuwał Kain po popełnieniu grzechu i dopatruje się w tym także kary Bożej. Na tym jednak tragedia Kaina się nie kończy, ponieważ spotkało go jeszcze jedno przekleństwo Boga: mimo uprawy roli będzie odczuwał brak plonów z tej ziemi.

$* * *$

Podsumowując wypowiedzi Ojców Kościoła na temat grzechu Kaina należy podkreślić, że poświęcają mu dosyć dużo miejsca. Starannie analizują tekst biblijny Rdz 4, 1-16 i zwracają uwagę na wiele szczegółów. Można nawet stwierdzić, że przedstawiają moralny i psychologiczny portret Kaina. Nie zatrzymują się wyłącznie na grzechu bratobójstwa, chociaż piętnują go najbardziej, ale skupiają swoją uwagę także na innych grzechach Kaina, które poprzedzały i doprowadziły do zabicia przez niego Abla.

Ojcowie Kościoła dostrzegają nie tylko indywidualny, ale też społeczny charakter popełnionych przez niego grzechów. Kain opuszcza przestrzeń obecności i działania Boga ze względu na swoją niegodność. Sam siebie oddziela od swoich krewnych, bo wie, że nie mógłby łączyć się z nim przez małżeństwo. Po Kainie rodzina stała się podzielona. Miejsce Nod, do którego się udaje i gdzie zamieszkuje, oznacza ciagłe wędrowanie, ale też jest ono pełne niepokoju i pozbawione plonów ziemi.

Ważne w komentowanych tekstach Ojców jest także zwrócenie uwagi na miłosierdzie Boga i gotowość do przebaczenia. Komentatorzy tekstu biblijnego Rdz 4, 1-16 nie dostrzegają u Kaina nawrócenia z jakiegokolwiek popełnionego przez niego grzechu. Brat Abla pozostał niewzruszony wobec Boga, zakłamany i narzekający na wielkość nałożonej na niego kary. Innego zdania są Ojcowie, którzy dostrzegają w tym Bożą pedagogię, mądrość Boga i wyjście Kainowi naprzeciw.

${ }^{37}$ Ephraem Syrus, Commentarius in Genesim III 11, CSCO 152, 52, thum. własne wg Tonneau, CSCO 153, 41. 
THE SIN OF CAIN IN THE ASSESSMENT OF THE CHURCH FATHERS

\section{(Summary)}

Fathers of the Church have left comments on Genesis as well as other works, which explain not only the biblical descriptions of the origins of the world and man, but also Gen 4: 1-16, where it speaks of the sin of Cain. In this paper we present an assessment of the sin of Cain made by some of the Fathers of the Church. It should be noted that they do not stop only on the sin of fratricide, although condemn it the most, but focus their attention also on other sins of Cain, which preceded and led to the killing of Abel by his jealousy, anger, evil thoughts, insincerity. Fathers of the Church recognize the individual and social character of the sins of Cain, which manifests itself in leaving his from God and separation from relatives. This resulted in a permanent division of the family. Fathers also point to the mercy of God and a willingness to forgive. Commentators of Gen 4:1-16 biblical text, however, do not see in Cain repent for any sin committed by him.

Key words: Cain, sin, Abel, fratricide, conversion.

Słowa kluczowe: Kain, grzech, Abel, bratobójstwo, nawrócenie.

\section{BIBLIOGRAFIA}

\section{Źródła}

Ambrosius, De fuga saeculi, ed. K. Schenkl, CSEL 32/2, Vienna 1897, 163-207, thum.

W. Szołdrski: Św. Ambroży, O ucieczce od świata, w: Św. Ambroży, Wybór pism, PSP 7, Warszawa 1971, 89-128.

Ambrosius, Epistulae, ed. O. Faller, CSEL 82/1, Vienna 1968, tłum. P. Nowak: Św. Ambroży, Listy (1-35), t. 1, BOK 9, Kraków 1997, 31-253.

Athanasius, Epistulae festales (versio syriaca), The Festal Letters of Athanasius in an ancient Syriac Version, ed. W. Cureton, London 1848.

Augustinus, De civitate Dei, PL 41, tłum. W. Kornatowski: Św. Augustyn, O Państwie Bożym, t. I-II, Warszawa 1977.

Augustinus, Epistulae, ed. A. Goldbacher, CSEL 34/1-2, Vindobonae 1895, 1898.

Beda Venerabilis, Homiliarum ewangelii, ed. D. Hurst, CCL 122, Turnhout 1955.

Clemens Alexandrinus, Stromateis, PG 8, 685-1383, tłum. J. Niemirska-Pliszczyńska:

Klemens Aleksandryjski, Kobierce zapisków filozoficznych dotyczqcych prawdziwej wiedzy, t. 1-2, Warszawa 1994.

Cyrillus Hierosolymitanus, Ad illuminandos catechesis, PG 33, 331-1064, thum. W. Kania: Cyryl Jerozolimski, Katechezy przedchrzcielne i mistagogiczne, BOK 14, Kraków 2000.

Ephraem Syrus, Commentarius in Genesim, ed. R.M. Tonneau, CSCO 152-153 (Scriptores Syri 71-72), Louvain 1955.

Ephraem Syrus, Hymni de Paradiso, ed. E. Beck, CSCO 174, Louvain 1957. 
Joannes Chrysostomus, Adversus Judaeos, PG 48, 843-942, tłum. J. Iluk: Św. Jan Chryzostom, Mowy przeciwko Judaizantom i Żydom, ŹMT 41, Kraków 2007, 53-226.

Joannes Chrysostomus, In Genesim homiliae, PG 53, 21 - 54, 580.

Maximus Taurinensis, Sermones, ed. A. Mutzenbecher, CCL 23, Turnhout 1962.

Origenes, De oratione, PG 11, 425-462, thum. W. Kania - H. Pietras, w: H. Pietras, Odpowiedź na Słowo. Najstarsi mistrzowie chrześcijańskiej modlitwy, Kraków 1993, 99-240.

ORIGENES, Exhortatio ad martyrium 50, PG 11, 563-638, tłum. S. Kalinkowski: Orygenes, Zachęta do męczeństwa, PSP 24, Warszawa 1980, 138-173.

Salvianus Massiliensis, De gubernatione Dei, ed. G. Lagarrigue, SCh 220, Paris 1975, tłum. T. Kołosowski: Salwian z Marsylii, O rzadach Boga, w: Salwian z Marsylii, Dzieła wszystkie, PSP 66, Warszawa 2010, 97-255.

Simeon Novus Theologus (= Simeon Junior) Catecheses, ed. B. Krivochéine - J. Paramelle, t. 1, SCh 96, Paris 1963; t. 2, SCh 104, Paris 1964.

\section{Opracowania}

Bosak P.Cz., Leksykon wszystkich postaci biblijnych, Kraków 2015.

Costacurta B., Obietnica życia w Księdze Rodzaju, przekł. D. Piekarz, Kraków 2005.

Praktyczny Słownik Biblijny, red. A. Grabner-Haider, tłum. T. Mieszkowski - P. Pachciarek, Warszawa 1994.

Rubinkiewicz R., Kain, EK VIII 328.

Słownik Teologii Biblijnej, red. X. Léon-Dufour, tłum. K. Romaniuk, Poznań - Warszawa 1982.

STACHOwiaK L., Grzech pierworodny, EK VI 281-282. 